\title{
Effects of Quercetin and Resveratrol on Zinc Chloride- and Sodium Metavanadate-Induced Passive Avoidance Memory Retention Deficits in Male Mice
}

\author{
Mahmoud Hashemzaei ${ }^{1,2}$, Sahar Fanoudi ${ }^{3}$, Mohadeseh Najari ${ }^{4}$, Mansoureh Fotouhi ${ }^{4}$, Maryam Belaran ${ }^{5}$, \\ Najmeh Sadat Alipour ${ }^{4}$, Zahra Dadrezaei ${ }^{4}$, Fatemeh Miri ${ }^{4}$, and Kaveh Tabrizian ${ }^{1,2}$ \\ ${ }^{1}$ Department of Pharmacology and Toxicology, Faculty of Pharmacy, ${ }^{2}$ Toxicology and Addiction Research Center, \\ ${ }^{4}$ Students Research Committee, Faculty of Pharmacy, and ${ }^{5}$ Department of Physiology, Faculty of Medicine, \\ Zabol University of Medical Sciences, Zabol 98616-15881, Iran \\ ${ }^{3}$ Department of Pharmacology, School of Medicine, Mashhad University of Medical Sciences, Mashhad 13131-99137, Iran
}

\begin{abstract}
Quercetin and resveratrol are found in a variety of fruits and vegetables and have several biological and pharmacological properties. In this study, the effects of quercetin $[50 \mathrm{mg} / \mathrm{kg}$, intraperitoneal (i.p.)] and resveratrol (50 mg/kg, i.p.) on zinc chloride $\left(\mathrm{ZnCl}_{2} ; 75 \mathrm{mg} / \mathrm{kg} / \mathrm{d}, 2\right.$ weeks oral gavage) and sodium metavanadate (SMV; $22.5 \mathrm{mg} / \mathrm{kg} / \mathrm{d}, 2 \mathrm{weeks}$ oral gavage) induced passive avoidance memory retention were investigated in step-through passive avoidance tasks. $\mathrm{ZnCl}_{2}$ was dissolved in saline and SMV was dissolved in drinking water. Mice received $\mathrm{ZnCl}_{2}$ or SMV orally for two weeks and were administered quercetin or resveratrol by i.p. injection on day 14, days 12 and 14, or days 10, 12, and 14. At the end of treatment, animals were trained for one day in a step-through passive avoidance task, then alterations in avoidance memory retention were evaluated after $24,48,96$, and $168 \mathrm{~h}$. Oral consumption of $\mathrm{ZnCl}_{2}$ and SMV decreased latency time compared with control groups. Both quercetin and resveratrol $\left(50 \mathrm{mg} / \mathrm{kg}\right.$, i.p.) prevented $\mathrm{ZnCl}_{2}$ - and SMV-induced avoidance memory retention impairments and did not significantly alter muscle strength, as demonstrated in rotarod tasks. No significant differences were observed between mice who received single, double, or triple doses of quercetin or resveratrol. The results suggest that quercetin and resveratrol may have preventive effects on $\mathrm{ZnCl}_{2}$ - and SMV-induced memory impairment in male mice.
\end{abstract}

Keywords: quercetin, resveratrol, sodium metavanadate, step-through task, zinc chloride

\section{INTRODUCTION}

Many compounds in fruit and vegetables such as resveratrol and quercetin exhibit anti-aging properties. Targeting these mechanisms may help alleviate aging-dependent learning and memory deficiencies (Baur and Sinclair, 2006).

Resveratrol is a polyphenol phytoalexin found in the skin of red grapes (Jang et al., 1997; Vinson, 1998). Resveratrol has been shown to inhibit or slow the development of various diseases including cardiovascular disorders, cancer, Alzheimer's disease (AD), and ischemic injuries (Bradamante et al., 2004; Baur and Sinclair, 2006), acting via its antioxidant, anti-inflammatory, and neuroprotective properties (Baur and Sinclair, 2006; Saiko et al., 2008). Furthermore, resveratrol has been shown to reduce toxicity induced by amyloid beta $(\mathrm{A} \beta)$ peptides (Han et al., 2004; Anekonda, 2006) and kainic acid (Wang et al., 2004) to prevent cerebral ischemic damage (Wang et al., 2002), improve cognitive function in a senescenceaccelerated mouse prone 8 model of $\mathrm{AD}$ (Porquet et al., 2013), and improve memory deficit induced by scopolamine (Gacar et al., 2011) or streptozotocin (Sharma and Gupta, 2002). In addition, other studies have illustrated that resveratrol could be a beneficial for treatment of $\mathrm{AD}$ (Ono et al., 2008; Turner et al., 2015), with its neuroprotective properties attributed to its antioxidant activity (Poulose et al., 2015).

The flavonoid compound quercetin (3,3',4',5,7-pentahydroxyflavone dihydrate) is found in fruits, vegetables, 
leaves, and grains (Silva et al., 2008) and contains important antioxidant and free radical scavenger activities (Saponara et al., 2002). Quercetin is involved in activation and stimulation of neurogenesis (Tchantchou et al., 2009), and can easily pass through the blood-brain barrier (BBB) to help decrease neurodegenerative alterations and age-related neurocognitive impairment (Manach et al., 2004; Youdim et al., 2004; Rogerio et al., 2007). Moreover, quercetin has shown neuroprotective effects against oxidative stress and $A \beta$ accumulation in in vitro and in vivo models (Cho et al., 2006; Zhu et al., 2007).

Zinc ( $\mathrm{Zn})$ is an essential element that plays a central role in various physiological processes, including immune system function and protein synthesis, and is a co-factor for several enzymes (Frassinetti et al., 2006). Zn has numerous structural, catalytic, and regulatory functions in brain maturation, maintenance of mental functions and neurotransmission, and binds to certain receptors at critical periods of brain development (Sandstead et al., 1998; Durczok et al., 2005; Flinn et al., 2005; Boroujeni et al., 2009; Nuttall and Oteiza, 2014; Prakash et al., 2015; Warthon-Medina et al., 2015). The hippocampus has the highest content of $\mathrm{Zn}$ in the brain, suggesting that $\mathrm{Zn}$ is very important for hippocampal cognitive function and memory formation (Danscher et al., 1975; Greiner et al., 1975; Halas et al., 1983; Frederickson et al., 1987; Chu et al., 2003; Takeda et al., 2005; Boroujeni et al., 2009; Takeda, 2012; Młyniec et al., 2014; Takeda et al., 2015). The hippocampus is part of limbic system and has a major role in spatial learning and memory. Damage of one or both parts of the hippocampus causes behavioral changes and deficits in learning about people, places, and objects (Bannerman et al., 2002; Vitolo et al., 2002; Longoni et al., 2015). Although Zn deficiency can alter spatial learning and memory by changing neurotransmitter content and receptor activity (Halas et al., 1983; Sandstead, 1985; Halas et al., 1986; Golub et al., 1995; Keller et al., 2001; Bitanihirwe and Cunningham, 2009; Kida et al., 2015), excess $\mathrm{Zn}$ induces central nervous system (CNS) pathology (Hamadani et al., 2002; Tamura et al., 2003; Flinn et al., 2005; Bitanihirwe and Cunningham, 2009; Suzuki et al., 2015; Contestabile et al., 2016; Tabrizian et al., 2016). Indeed, high levels of $\mathrm{Zn}$ can induce apoptosis and cytotoxicity in neural cells (Bitanihirwe and Cunningham, 2009). Thus, the $\mathrm{Zn}$ balance is essential for CNS development, normal behavior, and preventing neurological diseases such as $\mathrm{AD}$, epilepsy, amyotrophic lateral sclerosis, and ischemia (Seven et al., 2013; Prakash et al., 2015).

Vanadium $(\mathrm{V})$ is a metal widely distributed in the environment. $\mathrm{V}$ can induce toxic effects on different biological systems including the nervous system (Azami et al., 2012), and is involved in weight loss (Sanchez et al., 1998), morphological and biochemical alterations in different organs (al-Bayati et al., 1989), thrombocytopenia
(González-Villalva et al., 2006), male reproductive system toxicity (Fortoul et al., 2007), hematological abnormalities (Zaporowska and Wasilewski, 1989), and CNS neurotoxicity (Garcia et al., 2005). In addition, V exposure can reduce visual memory, and induce mood disorders and motor disturbances (Zhou et al., 2007). Indeed, V toxicity impairs learning and spatial memory in animal models (Sanchez et al., 1998; Avila-Costa et al., 2006; Mao et al., 2008), chiefly manifesting as CNS depression and tremors in human (Afeseh Ngwa et al., 2009). Moreover, $\mathrm{V}$ exposure in male mice induces hippocampal CA1 damage (Avila-Costa et al., 2006).

The present study was designed to investigate the effects of resveratrol and quercetin as natural pharmacological agents on changes to avoidance memory retention induced by zinc chloride $\left(\mathrm{ZnCl}_{2}\right)$ and sodium metavanadate (SMV) in male mice by using step-through passive avoidance learning tasks.

\section{MATERIALS AND METHODS}

\section{Animals}

Animal experiments were approved by the Committee for the Care and Use of Laboratory Animals in the Zabol University (Zbmu.1.REC.1394.150), conducted according to the guidelines for the care and use of laboratory animals of Zabol University of Medical Sciences. Male albino mice $(20 \sim 25 \mathrm{~g})$ at $8 \sim 10$ weeks of age were obtained from the Faculty of Pharmacy, Zabol University of Medical Sciences. All animals were maintained under controlled conditions (12-h light/dark cycle at room temperature of $20 \sim 22^{\circ} \mathrm{C}$ ) and housed five per cage with free access to standard lab chow and tap water. All animal experiments were carried out during the light cycle. For all experiments, mice were split into groups of 8 .

\section{Drugs}

$\mathrm{ZnCl}_{2}$ (Merck KGaA, Darmstadt, Germany) and SMV (Merck KGaA) were dissolved in saline $(0.9 \%)$ and drinking water, respectively, to obtain desirable concentrations. Quercetin and resveratrol were purchased from Sigma-Aldrich Co. (St. Louis, MO, USA). The required amount of resveratrol or quercetin powder was dissolved in $1 \mathrm{~mL}$ dimethyl sulfoxide and diluted with normal saline.

\section{Step-through avoidance learning tasks}

Details of the passive avoidance apparatus were described previously (Ader et al., 1972). In this study, each mouse was placed in the light chamber, and the door was opened after $10 \mathrm{~s}$. The time taken for the mouse to cross into the dark chamber was recorded as the latency time (300 $\mathrm{s}$ was determined as the cut-off point). Electric shocks 
( $0.2 \mathrm{~mA}$ intensity for $2 \mathrm{~s}$ ) were administered to the grid floor of the dark compartment. All training and testing trials were carried out at a similar time during the morning. During the retention test sessions, no electric shocks were applied.

\section{Rotarod tests}

Motor coordination and balance were tested using rotarod apparatus. Animals were initially placed on a rotating drum (rotation speed of $0 \sim 40 \mathrm{rpm}$ ) of rotarod and trained to walk. The speed of the device could be adjusted by changing the position of a belt. The rotary rod began to rotate at a speed of $5 \mathrm{rpm}$, reaching a maximum rotational speed of $20 \mathrm{rpm}$. Mice were placed on the drum of the rotarod for a maximum of $300 \mathrm{~s}$, and the amount of time each mouse could maintain its balance was recorded. This experiment was repeated three times for each mouse (Rabiei and Rafieian, 2014).

\section{Experiments}

Experiment 1: Fresh solutions of $\mathrm{ZnCl}_{2}$ in normal saline were prepared daily. $\mathrm{ZnCl}_{2}$ (75 mg/kg/d) or saline (controls) was administered via oral gavage needles once a day for two weeks. In addition, quercetin or resveratrol were administered by intraperitoneal (i.p.) injection on days 14,12 , and 14, or 10, 12, and 14 of treatment. Avoidance memory retention tests were carried out at day 14 (in mice not administered quercetin or resveratrol) and after 24, 48, 96, and $168 \mathrm{~h}$ after training trials (in mice administered quercetin or resveratrol). For all animals, muscle strength was assessed using rotarod tasks.

Experiment 2: Fresh solutions of SMV in drinking water were prepared daily. SMV $(22.5 \mathrm{mg} / \mathrm{kg} / \mathrm{d}$ ) or saline (controls) was administered via oral gavage needles once a day for two weeks. In addition, quercetin or resveratrol were administered by i.p. injection on days 14, 12, and 14, or 10,12 , and 14 of treatment. Avoidance memory retention tests were carried out at day 14 (in mice not administered quercetin or resveratrol) and at 24, 48, 96, and 168 $\mathrm{h}$ after training trials (in mice administered quercetin or resveratrol). For all animals, muscle strength was assessed using rotarod tasks.

\section{Statistical analysis}

Data were analyzed using GraphPad Prism version 5.0 (GraphPad Software, San Diego, CA, USA). We performed one-way analysis of variance (ANOVA) followed by Newman-Keuls post hoc test to compare results of our behavioral studies. Values were considered statistically significant at $P<0.05$.

\section{RESULTS}

\section{Effects of quercetin or resveratrol on $\mathrm{ZnCl}_{2}$-induced pas- sive avoidance memory retention impairments in step- through tasks}

Pre-training oral administration of $\mathrm{ZnCl}_{2}(75 \mathrm{mg} / \mathrm{kg} / \mathrm{d})$ for 14 consecutive days significantly decreased stepthrough latency times (s) during the retention tests. In addition, quercetin $(50 \mathrm{mg} / \mathrm{kg}$, i.p.; Table 1) and resveratrol $\left(50 \mathrm{mg} / \mathrm{kg}\right.$, i.p.; Table 2) prevented $\mathrm{ZnCl}_{2}$-induced avoidance memory retention impairment and did not significantly alter muscle strength, as demonstrated in rotarod tasks (data not shown). Quercetin (single, double, and triple doses) significantly inhibited $\mathrm{ZnCl}_{2}$-induced memory retention impairments (measured 24, 48, 96, and $168 \mathrm{~h}$ after training trials) in step-through avoidance tasks. However, there were not significant differences between single, double and triple doses of quercetin or resveratrol. For resveratrol-treated mice, those that received resveratrol (on days 10, 12, and 14 of $\mathrm{ZnCl}_{2}$ treatment) showed better responses at 48,96 , and $168 \mathrm{~h}$ after the training trials.

Effects of quercetin or resveratrol on SMV-induced passive avoidance memory retention impairments in step-through tasks

Pre-training oral administration of SMV $(22.5 \mathrm{mg} / \mathrm{kg} / \mathrm{d})$ for 14 consecutive days significantly decreased stepthrough latency times (s) during the retention tests. In addition, quercetin $(50 \mathrm{mg} / \mathrm{kg}$, i.p.; Table 3$)$ and resveratrol $\left(50 \mathrm{mg} / \mathrm{kg}\right.$, i.p.; Table 4) prevented $\mathrm{ZnCl}_{2}$-induced avoidance memory retention impairment and did not significantly alter muscle strength, as demonstrated in the

Table 1. Effects of quercetin on $\mathrm{ZnCl}_{2}$-induced passive avoidance memory retention alterations in step-through tasks

\begin{tabular}{lcccc}
\hline & $24 \mathrm{~h}$ & $48 \mathrm{~h}$ & $96 \mathrm{~h}$ & $168 \mathrm{~h}$ \\
\hline Control & $291.10 \pm 6.36$ & $260.00 \pm 40.03$ & $270.80 \pm 27.99$ & $281.50 \pm 12.50$ \\
$\mathrm{ZnCl}(75 \mathrm{mg} / \mathrm{kg} / \mathrm{d})$ & $20.17 \pm 4.04^{* * *}$ & $24.80 \pm 10.34^{* * *}$ & $22.67 \pm 3.80^{* * *}$ & $42.00 \pm 13.95^{* * *}$ \\
$\mathrm{ZnCl}+\mathrm{Q}_{1}$ & $122.20 \pm 17.00^{* * * \# \# \#}$ & $157.00 \pm 30.77^{\#}$ & $133.40 \pm 19.72^{* * \# \#}$ & $155.30 \pm 48.75^{\#}$ \\
$\mathrm{ZnCl}_{2}+\mathrm{Q}_{2}$ & $164.10 \pm 18.05^{* * * \# \#}$ & $181.30 \pm 55.46^{\#}$ & $152.60 \pm 41.47^{* * \# \#}$ & $225.70 \pm 40.12^{\# \#}$ \\
$\mathrm{ZnCl}_{2}+\mathrm{Q}_{3}$ & $130.20 \pm 10.88^{* * * \# \#}$ & $133.20 \pm 32.59^{\#}$ & $172.70 \pm 21.40^{* \# \#}$ & $223.90 \pm 33.59^{\# \#}$ \\
\hline
\end{tabular}

Values are means \pm SEM of 8 mice per group.

${ }^{*} P<0.05,{ }^{* *} P<0.01$, and ${ }^{* * *} P<0.001$ show a considerable difference from the control group and ${ }^{\#} P<0.05,{ }^{\# \#} P<0.01$, and ${ }^{\# \# \#} P<0.001$ show a considerable difference from the $\mathrm{ZnCl}_{2}$-treated group.

$Q_{1}, Q_{2}$, and $Q_{3}$ : single, double, and triple doses of quercetin, respectively. 
Table 2. Effects of resveratrol on $\mathrm{ZnCl}_{2}$-induced passive avoidance memory retention alterations in step-through tasks

\begin{tabular}{lcccc}
\hline & $24 \mathrm{~h}$ & $48 \mathrm{~h}$ & $96 \mathrm{~h}$ & $168 \mathrm{~h}$ \\
\hline Control & $202.00 \pm 49.24$ & $252.00 \pm 48.04$ & $252.00 \pm 48.04$ & $238.20 \pm 29.82$ \\
$\mathrm{ZnCl}_{2}(75 \mathrm{mg} / \mathrm{kg} / \mathrm{d})$ & $19.58 \pm 4.90^{* *}$ & $26.86 \pm 12.41^{* * *}$ & $26.86 \pm 12.41^{* *}$ & $22.24 \pm 7.14^{* * *}$ \\
$\mathrm{ZnCl}_{2}+\mathrm{RSV}_{1}$ & $74.00 \pm 17.49$ & $109.40 \pm 23.80^{*}$ & $111.60 \pm 49.97$ & $76.40 \pm 10.77^{* * *}$ \\
$\mathrm{ZnCl}_{2}+\mathrm{RSV}_{2}$ & $76.20 \pm 12.00$ & $137.80 \pm 19.82^{* \#}$ & $155.60 \pm 28.69$ & $85.00 \pm 21.45^{* * *}$ \\
$\mathrm{ZnCl}_{2}+\mathrm{RSV}_{3}$ & $102.40 \pm 51.35$ & $172.00 \pm 32.47^{\#}$ & $216.60 \pm 43.70^{\#}$ & $112.20 \pm 22.61^{* * * \#}$ \\
\hline
\end{tabular}

Values are means \pm SEM of 8 mice per group.

${ }^{*} P<0.05,{ }^{* *} P<0.01$, and ${ }^{* * *} P<0.001$ show a considerable difference from the control group and ${ }^{\#} P<0.05,{ }^{\# \#} P<0.01$, and ${ }^{\# \#} P<0.001$ show a considerable difference from the $\mathrm{ZnCl}_{2}$-treated group.

$\mathrm{RSV}_{1}, \mathrm{RSV}_{2}$, and $\mathrm{RSV}_{3}$ : single, double, and triple doses of resveratrol, respectively.

Table 3. Effects of quercetin on sodium metavanadate (SMV)-induced passive avoidance memory retention alterations in step-through tasks

\begin{tabular}{lcccc}
\hline & $24 \mathrm{~h}$ & $48 \mathrm{~h}$ & $96 \mathrm{~h}$ & $168 \mathrm{~h}$ \\
\hline Control & $285.70 \pm 6.39$ & $250.10 \pm 47.96$ & $250.10 \pm 48.87$ & $248.50 \pm 47.76$ \\
$\mathrm{SMV}(22.5 \mathrm{mg} / \mathrm{kg} / \mathrm{d})$ & $28.12 \pm 1.75^{* * *}$ & $32.95 \pm 12.63^{* * *}$ & $39.73 \pm 16.24^{* * *}$ & $56.28 \pm 26.59^{* * *}$ \\
$\mathrm{~S} M V+Q_{1}$ & $148.10 \pm 12.43^{* * *}$ & $214.90 \pm 29.15^{* * * \# \#}$ & $179.00 \pm 27.07^{* * * \# \#}$ & $193.40 \pm 30.48^{* * * \# \#}$ \\
$\mathrm{SMV}+\mathrm{Q}_{2}$ & $163.40 \pm 27.59^{* * *}$ & $165.70 \pm 22.89^{\# \#}$ & $164.90 \pm 24.65^{\# \#}$ & $213.30 \pm 39.19^{\# \#}$ \\
$\mathrm{SMV}+Q_{3}$ & $142.80 \pm 38.00^{* * *}$ & $192.20 \pm 27.04^{\# \#}$ & $189.40 \pm 29.49^{\# \#}$ & $251.90 \pm 30.53^{\# \#}$ \\
\hline
\end{tabular}

Values are means \pm SEM of 8 mice per group.

${ }^{* * *} P<0.001$ shows a considerable difference from the control group and ${ }^{\#} P<0.05$ and ${ }^{\# \#} P<0.01$ show a considerable difference from the SMV-treated group.

$Q_{1}, Q_{2}$, and $Q_{3}$ : single, double, and triple doses of quercetin, respectively.

Table 4. Effects of resveratrol on sodium metavanadate (SMV)-induced passive avoidance memory retention alterations in step-through tasks

\begin{tabular}{lcccc}
\hline & $24 \mathrm{~h}$ & $48 \mathrm{~h}$ & $96 \mathrm{~h}$ & $168 \mathrm{~h}$ \\
\hline Control & $295.80 \pm 2.57$ & $298.00 \pm 2.00$ & $280.00 \pm 20.00$ & $276.20 \pm 19.40$ \\
SMV (22.5 mg/kg/d) & $26.12 \pm 2.82^{* * *}$ & $20.14 \pm 2.42^{* * *}$ & $22.64 \pm 1.26^{* * *}$ & $26.72 \pm 4.46^{* * *}$ \\
SMV + RSV & $44.64 \pm 24.12^{* * *}$ & $79.88 \pm 35.52^{* * *}$ & $22.64 \pm 6.68^{* * *}$ & $42.00 \pm 13.19^{* * *}$ \\
SMV + RSV & $97.80 \pm 52.15^{* *}$ & $83.80 \pm 40.86^{* * *}$ & $20.56 \pm 8.21^{* * *}$ & $37.40 \pm 14.13^{* * *}$ \\
SMV + RSV & $147.60 \pm 58.58^{* *}$ & $196.00 \pm 38.29^{* \# \#}$ & $89.00 \pm 10.05^{* * * \# \#}$ & $74.00 \pm 20.15^{* * *}$ \\
\hline
\end{tabular}

Values are means \pm SEM of 8 mice per group.

${ }^{*} P<0.05,{ }^{* *} P<0.01$, and ${ }^{* * *} P<0.001$ show a considerable difference from the control group and ${ }^{\# \#} P<0.01$ shows a considerable difference from the SMV-treated group.

$\mathrm{RSV}_{1}, \mathrm{RSV}_{2}$, and $\mathrm{RSV}_{3}$ : single, double, and triple doses of resveratrol, respectively.

rotarod tasks (data not shown). Quercetin (single, double, and triple doses) significantly inhibited SMV-induced memory retention impairments (at 48,96 , and $168 \mathrm{~h}$ after training trials) in step-through avoidance tasks. However, there were no significant differences between single, double and triple doses of quercetin or resveratrol. For resveratrol-treated mice, those that received triple doses resveratrol (on days 10, 12, and 14 of SMV treatment) showed better responses at 48 and $96 \mathrm{~h}$ after the training trials.

\section{DISCUSSION}

The results of this study demonstrated 2-week oral administration of $\mathrm{ZnCl}_{2}(75 \mathrm{mg} / \mathrm{kg} / \mathrm{d})$ and SMV $(22.5 \mathrm{mg} /$ $\mathrm{kg} / \mathrm{d}$ ) cause poor retrieval of learning behavior in passive avoidance tasks. In previous studies, elevated levels of $\mathrm{Zn}$ have been shown to be toxic for cognitive processes (Hamadani et al., 2002) and have been identified as a risk factor for $\mathrm{AD}$ (Cuajungco et al., 2000). However, an adequate amount of $\mathrm{Zn}$ consumed as part of a normal diet has an important role in memory processes, cognitive behavior, reducing oxidative stress (Ebuehi and Akande, 2008), and elevating cyclic nucleotide cyclic guanosine monophosphate, consequently activating protein kinase A (von Bülow et al., 2007; Hönscheid et al., 2012). However, studies have reported that $\mathrm{Zn}$ has detrimental effects on formation of neurotic plaques and deposition of cerebrovascular amyloid plaques in $\mathrm{AD}$ (Bitanihirwe and Cunningham, 2009). Indeed, $\mathrm{Zn}$ may induce oxidative stress and amyloid plaque formation, which causes memory loss (Bitanihirwe and Cunningham, 2009). Zn exhibits some regulatory roles through $\gamma$-amino butyric acid 
and $\mathrm{N}$-methyl-D-aspartate receptors in memory formation (Chowanadisai et al., 2005). For example, the inhibitory effects of $\mathrm{Zn}$ can cause spatial memory damage in rats and mice (Morris, 1989; Brun et al., 2001).

In previous studies, oral administration of SMV $(25 \mathrm{mg}$ $/ \mathrm{kg}$ ) before training has been suggested to impair spatial memory acquisition, as demonstrated in Morris water mazes, and reduce protein expression of cholinergic system markers [e.g., choline acetyltransferase (ChAT) and vesicular acetylcholine transporter] in the CA1 region of the hippocampus and medial septal area. In addition, SMV was shown to induce formation of reactive oxygen species and changes in oxidative state (Cuesta et al., 2011). Since oxidative damage has a major role in various disease such as cancer, aging, and some chronic disease, multiple studies have focused on the benefits of antioxidants for preventing and/or targeting these processes (Fahey and Talalay, 1999).

In the current study, treatment with resveratrol and quercetin significantly increased the latency time in retention trials, alleviating the retention latency induced by $\mathrm{ZnCl}_{2}$ and SMV. Quercetin is a major flavonoid compounds found in many fruits and vegetables, and exhibits stronger antioxidative and anticarcinogenic activities than vitamin C (Takahama, 1988; Heo and Lee, 2004). Quercetin can pass through the BBB of in situ models (Youdim et al., 2004) and has demonstrated protective effect in an animal model of stroke (Cho et al., 2006). Quercetin is absorbed after oral consumption and passes through the BBB due to its lipophilicity and the action of efflux transporters such as P-glycoprotein (Lin and Yamazaki, 2003; Youdim et al., 2003).

A neuroprotective effect of quercetin against 6-hydroxydopamine-induced oxidative damage was previously demonstrated (Kim et al., 2004). Furthermore, animals administered quercetin exhibited acetylcholinesterase (AChE) activity in the homogenate of the hippocampus, indicative of improved cognitive performance due to enhanced acetylcholine at the synaptic terminals (Sriraksa et al., 2012). In addition, other studies have revealed that quercetin competitively inhibits AChE (Islam et al., 2013; Maciel et al., 2016; Suganthy et al., 2016).

Resveratrol has been well-documents to have anti-inflammatory effects (Švajger and Jeras, 2012) that can be protective against and decrease cognitive deficiency in normal aging via reducing levels of interleukin-1 $\beta$ and tumor necrosis factor- $\alpha$ (Gocmez et al., 2016). Furthermore, resveratrol can enhance cognitive function by neurogenesis and angiogenesis, thus acting to directly improve function of brain (Kodali et al., 2015). In addition, resveratrol can upregulate brain-derived neurotrophic factor (BDNF) levels in the hippocampus and amygdala of chronic mild unpredictable stress-exposed rats, which improves cognition (Yazir et al., 2015). Moreover, resver- atrol has been shown to improve learning and memory function through the microRNA-cyclic adenosine monophosphate-response element binding protein-BDNF pathway in normal aged mice (Zhao et al., 2013), and to ameliorate the decreased learning and memory of $\mathrm{AD}$ model mice via decreasing $\mathrm{AChE}$ activity and increasing ChAT activity and acetylcholine content (Wang et al., 2017).

Quercetin acts to promote learning and memory performance through regulating acetylcholine esterase bioactivity, neurotrophic factors levels, oxidative status, anti-apoptotic gene expression, and $\mathrm{A} \beta$ fibril formation inhibition (Kumar et al., 2008; Bournival et al., 2009; Bhutada et al., 2010; Tongjaroenbuangam et al., 2011; Liu et al., 2013). Furthermore, quercetin increases proliferation, migration, and differentiation of rat neural stem cells (Kee et al., 2007; Clelland et al., 2009; Garthe et al., 2009) and increases expression of genes involved in neurogenesis (Spencer et al., 2003; Spencer, 2007).

In conclusion, this study demonstrated that administration of resveratrol and quercetin protects against cognitive impairments induced by $\mathrm{ZnCl}_{2}$ and SMV in mice. Therefore, resveratrol and quercetin may represent new treatment opportunities for AD.

\section{ACKNOWLEDGEMENTS}

The authors would like to sincerely thank Zabol University of Medical Sciences and Students Research Committee of Zabol University of Medical Sciences for the approval and financial support of this research. The results presented in this paper were part of a Pharm. D. thesis.

\section{AUTHOR DISCLOSURE STATEMENT}

The authors declare no conflict of interest.

\section{REFERENCES}

Ader R, Weijnen JAWM, Moleman P. Retention of a passive avoidance response as a function of the intensity and duration of electric shock. Psychon Sci. 1972: 26:125-128.

Afeseh Ngwa H, Kanthasamy A, Anantharam V, Song C, Witte T, Houk R, et al. Vanadium induces dopaminergic neurotoxicity via protein kinase $\mathrm{C}$-delta dependent oxidative signaling mechanisms: relevance to etiopathogenesis of Parkinson's disease. Toxicol Appl Pharmacol. 2009. 240:273-285.

al-Bayati MA, Giri SN, Raabe OG, Rosenblatt LS, Shifrine M. Time and dose-response study of the effects of vanadate on rats: morphological and biochemical changes in organs. J Environ Pathol Toxicol Oncol. 1989. 9:435-455.

Anekonda TS. Resveratrol - a boon for treating Alzheimer's disease?. Brain Res Rev. 2006. 52:316-326.

Avila-Costa MR, Fortoul TI, Niño-Cabrera G, Colín-Barenque L, Bizarro-Nevares P, Gutiérrez-Valdez AL, et al. Hippocampal cell 
alterations induced by the inhalation of vanadium pentoxide $\left(\mathrm{V}_{2} \mathrm{O}_{5}\right)$ promote memory deterioration. NeuroToxicology. 2006. 27:1007-1012.

Azami K, Tabrizian K, Hosseini R, Seyedabadi M, Shariatpanahi $M$, Noorbakhsh F, et al. Nicotine attenuates spatial learning deficits induced by sodium metavanadate. NeuroToxicology. 2012. 33:44-52.

Bannerman DM, Deacon RM, Offen S, Friswell J, Grubb M, Rawlins JN. Double dissociation of function within the hippocampus: spatial memory and hyponeophagia. Behav Neurosci. 2002. 16:884-901.

Baur JA, Sinclair DA. Therapeutic potential of resveratrol: the in vivo evidence. Nat Rev Drug Discov. 2006. 5:493-506.

Bhutada P, Mundhada Y, Bansod K, Bhutada C, Tawari S, Dixit P, et al. Ameliorative effect of quercetin on memory dysfunction in streptozotocin-induced diabetic rats. Neurobiol Learn Mem. 2010. 94:293-302.

Bitanihirwe BK, Cunningham MG. Zinc: the brain's dark horse. Synapse. 2009. 63:1029-1049.

Boroujeni ST, Naghdi N, Shahbazi M, Farrokhi A, Bagherzadeh F, Kazemnejad A, et al. The effect of severe zinc deficiency and zinc supplement on spatial learning and memory. Biol Trace Elem Res. 2009. 130:48-61.

Bournival J, Quessy P, Martinoli MG. Protective effects of resveratrol and quercetin against $\mathrm{MPP}^{+}$-induced oxidative stress act by modulating markers of apoptotic death in dopaminergic neurons. Cell Mol Neurobiol. 2009. 29:1169-1180.

Bradamante S, Barenghi L, Villa A. Cardiovascular protective effects of resveratrol. Cardiovasc Drug Rev. 2004. 22:169-188.

Brun VH, Ytterbo K, Morris RG, Moser MB, Moser EI. Retrograde amnesia for spatial memory induced by NMDA receptor-mediated long-term potentiation. J Neurosci. 2001. 21:356-362.

Cho JY, Kim IS, Jang YH, Kim AR, Lee SR. Protective effect of quercetin, a natural flavonoid against neuronal damage after transient global cerebral ischemia. Neurosci Lett. 2006. 404:330335.

Chowanadisai W, Kelleher SL, Lönnerdal B. Maternal zinc deficiency reduces NMDA receptor expression in neonatal rat brain, which persists into early adulthood. J Neurochem. 2005. 94: 510-519.

Chu Y, Mouat MF, Harris RBS, Coffield JA, Grider A. Water maze performance and changes in serum corticosterone levels in zinc-deprived and pair-fed rats. Physiol Behav. 2003. 78:569578.

Clelland CD, Choi M, Romberg C, Clemenson GD Jr, Fragniere A, Tyers $\mathrm{P}$, et al. A functional role for adult hippocampal neurogenesis in spatial pattern separation. Science. 2009. 325:210213.

Contestabile A, Peña-Altamira E, Virgili M, Monti B. Zinc supplementation in rats impairs hippocampal-dependent memory consolidation and dampens post-traumatic recollection of stressful event. Eur Neuropsychopharmacol. 2016. 26:10701082.

Cuajungco MP, Goldstein LE, Nunomura A, Smith MA, Lim JT, Atwood CS, et al. Evidence that the $\beta$-amyloid plaques of Alzheimer's disease represent the redox-silencing and entombment of A $\beta$ by zinc. J Biol Chem. 2000. 275:19439-19442.

Cuesta S, Francés D, García GB. ROS formation and antioxidant status in brain areas of rats exposed to sodium metavanadate. Neurotoxicol Teratol. 2011. 33:297-302.

Danscher G, Hall E, Fredens K, Fjerdingstad E, Fjerdingstad EJ. Heavy metals in the amygdala of the rat: zinc, lead and copper. Brain Res. 1975. 94:167-172.

Durczok A, Szkilnik R, Nowak P, Labus Ł, Dąbrowska J, Bortel A, et al. The effects of zinc on the central dopaminergic system of rats prenatally exposed to cadmium. Pol J Environ Stud. 2005. 14:569-576.
Ebuehi OAT, Akande GA. Effect of zinc deficiency on memory, oxidative stress and blood chemistry in rats. Adv Med Dent Sci. 2008. 2:74-82.

Fahey JW, Talalay P. Antioxidant functions of sulforaphane: a potent inducer of phase II detoxication enzymes. Food Chem Toxicol. 1999. 37:973-979.

Flinn JM, Hunter D, Linkous DH, Lanzirotti A, Smith LN, Brightwell J, et al. Enhanced zinc consumption causes memory deficits and increased brain levels of zinc. Physiol Behav. 2005. 83:793-803.

Fortoul TI, Bizarro-Nevares P, Acevedo-Nava S, Piñón-Zárate G, Rodríguez-Lara V, Colín-Barenque L, et al. Ultrastructural findings in murine seminiferous tubules as a consequence of subchronic vanadium pentoxide inhalation. Reprod Toxicol. 2007. 23:588-592.

Frassinetti S, Bronzetti G, Caltavuturo L, Cini M, Croce CD. The role of zinc in life: a review. J Environ Pathol Toxicol Oncol. 2006. 25:597-610.

Frederickson CJ, Kasarskis EJ, Ringo D, Frederickson RE. A quinoline fluorescence method for visualizing and assaying the histochemically reactive zinc (bouton zinc) in the brain. J Neurosci Methods. 1987. 20:91-103.

Gacar N, Mutlu O, Utkan T, Komsuoglu Celikyurt I, Gocmez SS, Ulak G. Beneficial effects of resveratrol on scopolamine but not mecamylamine induced memory impairment in the passive avoidance and Morris water maze tests in rats. Pharmacol Biochem Behav. 2011. 99:316-323.

Garcia GB, Biancardi ME, Quiroga AD. Vanadium (V)-induced neurotoxicity in the rat central nervous system: a histo-immunohistochemical study. Drug Chem Toxicol. 2005. 28:329-344.

Garthe A, Behr J, Kempermann G. Adult-generated hippocampal neurons allow the flexible use of spatially precise learning strategies. PLoS One. 2009. 4:e5464. https://doi.org/10.1371/ journal.pone.0005464

Gocmez SS, Gacar N, Utkan T, Gacar G, Scarpace PJ, Tumer N. Protective effects of resveratrol on aging-induced cognitive impairment in rats. Neurobiol Learn Mem. 2016. 131:131-136.

Golub MS, Keen CL, Gershwin ME, Hendrickx AG. Developmental zinc deficiency and behavior. J Nutr. 1995. 125:2263S2271S.

González-Villalva A, Fortoul TI, Avila-Costa MR, Piñón-Zarate G, Rodriguez-Laraa V, Martínez-Levy G, et al. Thrombocytosis induced in mice after subacute and subchronic $\mathrm{V}_{2} \mathrm{O}_{5}$ inhalation. Toxicol Ind Health. 2006. 22:113-116.

Greiner AC, Chan SC, Nicholson GA. Determination of calcium, copper, magnesium, and zinc content of identical areas in human cerebral hemispheres of normals. Clin Chim Acta. 1975. 61:335-340.

Halas ES, Eberhardt MJ, Diers MA, Sandstead HH. Learning and memory impairment in adult rats due to severe zinc deficiency during lactation. Physiol Behav. 1983. 30:371-381.

Halas ES, Hunt CD, Eberhardt MJ. Learning and memory disabilities in young adult rats from mildly zinc deficient dams. Physiol Behav. 1986. 37:451-458.

Hamadani JD, Fuchs GJ, Osendarp SJ, Huda SN, GranthamMcGregor SM. Zinc supplementation during pregnancy and effects on mental development and behaviour of infants: a follow-up study. Lancet. 2002. 360:290-294.

Han YS, Zheng WH, Bastianetto S, Chabot JG, Quirion R. Neuroprotective effects of resveratrol against beta-amyloid-induced neurotoxicity in rat hippocampal neurons: involvement of protein kinase C. Br J Pharmacol. 2004. 141:997-1005.

Heo HJ, Lee CY. Protective effects of quercetin and vitamin C against oxidative stress-induced neurodegeneration. J Agric Food Chem. 2004. 52:7514-7517.

Hönscheid A, Dubben S, Rink L, Haase H. Zinc differentially regulates mitogen-activated protein kinases in human T cells. J 
Nutr Biochem. 2012. 23:18-26.

Islam MR, Zaman A, Jahan I, Chakravorty R, Chakraborty S. In silico QSAR analysis of quercetin reveals its potential as therapeutic drug for Alzheimer's disease. J Young Pharm. 2013. 5:173-179.

Jang M, Cai L, Udeani GO, Slowing KV, Thomas CF, Beecher CW, et al. Cancer chemopreventive activity of resveratrol, a natural product derived from grapes. Science. 1997. 275:218-220.

Kee N, Teixeira CM, Wang AH, Frankland PW. Preferential incorporation of adult-generated granule cells into spatial memory networks in the dentate gyrus. Nat Neurosci. 2007. 10: 355-362.

Keller KA, Grider A, Coffield JA. Age-dependent influence of dietary zinc restriction on short-term memory in male rats. Physiol Behav. 2001. 72:339-348.

Kida K, Tsuji T, Tanaka S, Kogo M. Zinc deficiency with reduced mastication impairs spatial memory in young adult mice. Physiol Behav. 2015. 152:231-237.

Kim MS, Lee JI, Lee WY, Kim SE. Neuroprotective effect of Ginkgo biloba L. extract in a rat model of Parkinson's disease. Phytother Res. 2004. 18:663-666.

Kodali M, Parihar VK, Hattiangady B, Mishra V, Shuai B, Shetty AK. Resveratrol prevents age-related memory and mood dysfunction with increased hippocampal neurogenesis and microvasculature, and reduced glial activation. Sci Rep. 2015. 5:8075. https://doi.org/10.1038/srep08075

Kumar A, Sehgal N, Kumar P, Padi SS, Naidu PS. Protective effect of quercetin against ICV colchicine-induced cognitive dysfunctions and oxidative damage in rats. Phytother Res. 2008. 22: 1563-1569.

Lin JH, Yamazaki M. Role of P-glycoprotein in pharmacokinetics: clinical implications. Clin Pharmacokinet. 2003. 42:59-98.

Liu R, Zhang TT, Zhou D, Bai XY, Zhou WL, Huang C, et al. Quercetin protects against the A $25-35$-induced amnesic injury: involvement of inactivation of RAGE-mediated pathway and conservation of the NVU. Neuropharmacology. 2013. 67:419431.

Longoni G, Rocca MA, Pagani E, Riccitelli GC, Colombo B, Rodegher M, et al. Deficits in memory and visuospatial learning correlate with regional hippocampal atrophy in MS. Brain Struct Funct. 2015. 220:435-444.

Maciel RM, Carvalho FB, Olabiyi AA, Schmatz R, Gutierres JM, Stefanello N, et al. Neuroprotective effects of quercetin on memory and anxiogenic-like behavior in diabetic rats: role of ectonucleotidases and acetylcholinesterase activities. Biomed Pharmacother. 2016. 84:559-568.

Manach C, Scalbert A, Morand C, Rémésy C, Jiménez L. Polyphenols: food sources and bioavailability. Am J Clin Nutr. 2004. 79:727-747.

Mao X, Zhang L, Xia Q, Sun Z, Zhao X, Cai H, et al. Vanadium-enriched chickpea sprout ameliorated hyperglycemia and impaired memory in streptozotocin-induced diabetes rats. Biometals. 2008. 21:563-570.

Młyniec K, Budziszewska B, Holst B, Ostachowicz B, Nowak G. GPR39 (zinc receptor) knockout mice exhibit depression-like behavior and CREB/BDNF down-regulation in the hippocampus. Int J Neuropsychopharmacol. 2014. 18:pyu002. https:// doi.org/10.1093/ijnp/pyu002

Morris RG. Synaptic plasticity and learning: selective impairment of learning rats and blockade of long-term potentiation in vivo by the $N$-methyl-D-aspartate receptor antagonist AP5. J Neurosci. 1989. 9:3040-3057.

Nuttall JR, Oteiza PI. Zinc and the aging brain. Genes Nutr. 2014. 9:379. https://doi.org/10.1007/s12263-013-0379-x

Ono K, Condron MM, Ho L, Wang J, Zhao W, Pasinetti GM, et al. Effects of grape seed-derived polyphenols on amyloid $\beta$-protein self-assembly and cytotoxicity. J Biol Chem. 2008. 283:
32176-32187.

Porquet D, Casadesús G, Bayod S, Vicente A, Canudas AM, Vilaplana J, et al. Dietary resveratrol prevents Alzheimer's markers and increases life span in SAMP8. Age. 2013. 35: 1851-1865.

Poulose SM, Thangthaeng N, Miller MG, Shukitt-Hale B. Effects of pterostilbene and resveratrol on brain and behavior. Neurochem Int. 2015. 89:227-233.

Prakash A, Bharti K, Majeed ABA. Zinc: indications in brain disorders. Fundam Clin Pharmacol. 2015. 29:131-149.

Rabiei Z, Rafieian M. Effects of Zizyphus jujuba extract on motor coordination impairment induced by bilateral electric lesions of the nucleus basalis of Meynert in rat. Physiol Pharmacol. 2014. 17:469-477.

Rogerio AP, Kanashiro A, Fontanari C, da Silva EV, LucisanoValim YM, Soares EG, et al. Anti-inflammatory activity of quercetin and isoquercitrin in experimental murine allergic asthma. Inflamm Res. 2007. 56:402-408.

Saiko P, Szakmary A, Jaeger W, Szekeres T. Resveratrol and its analogs: defense against cancer, coronary disease and neurodegenerative maladies or just a fad?. Mutat Res. 2008. 658:68-94.

Sanchez DJ, Colomina MT, Domingo JL. Effects of vanadium on activity and learning in rats. Physiol Behav. 1998. 63:345-350.

Sandstead HH, Penland JG, Alcock NW, Dayal HH, Chen XC, Li JS, et al. Effects of repletion with zinc and other micronutrients on neuropsychologic performance and growth of Chinese children. Am J Clin Nutr. 1998. 68:470S-475S.

Sandstead HH. Zinc: essentiality for brain development and function. Nutr Rev. 1985. 43:129-137.

Saponara S, Sgaragli G, Fusi F. Quercetin as a novel activator of L-type $\mathrm{Ca}^{2+}$ channels in rat tail artery smooth muscle cells. Br J Pharmacol. 2002. 135:1819-1827.

Seven M, Basaran SY, Cengiz M, Unal S, Yuksel A. Deficiency of selenium and zinc as a causative factor for idiopathic intractable epilepsy. Epilepsy Res. 2013. 104:35-39.

Sharma M, Gupta YK. Chronic treatment with trans resveratrol prevents intracerebroventricular streptozotocin induced cognitive impairment and oxidative stress in rats. Life Sci. 2002. 71:2489-2498.

Silva B, Oliveira PJ, Dias A, Malva JO. Quercetin, kaempferol and biapigenin from Hypericum perforatum are neuroprotective against excitotoxic insults. Neurotox Res. 2008. 13:265-279.

Spencer JP, Rice-Evans C, Williams RJ. Modulation of pro-survival Akt/protein kinase B and ERK1/2 signaling cascades by quercetin and its in vivo metabolites underlie their action on neuronal viability. J Biol Chem. 2003. 278:34783-34793.

Spencer JPE. The interactions of flavonoids within neuronal signalling pathways. Genes Nutr. 2007. 2:257-273.

Sriraksa N, Wattanathorn J, Muchimapura S, Tiamkao S, Brown $\mathrm{K}$, Chaisiwamongkol K. Cognitive-enhancing effect of quercetin in a rat model of Parkinson's disease induced by 6-hydroxydopamine. Evid Based Complement Alternat Med. 2012. 2012: 823206. https://doi.org/10.1155/2012/823206

Suganthy N, Devi KP, Nabavi SF, Braidy N, Nabavi SM. Bioactive effects of quercetin in the central nervous system: Focusing on the mechanisms of actions. Biomed Pharmacother. 2016. 84: 892-908.

Suzuki M, Fujise Y, Tsuchiya Y, Tamano H, Takeda A. Excess influx of $\mathrm{Zn}^{2+}$ into dentate granule cells affects object recognition memory via attenuated LTP. Neurochem Int. 2015. 87:6065.

Švajger U, Jeras M. Anti-inflammatory effects of resveratrol and its potential use in therapy of immune-mediated diseases. Int Rev Immunol. 2012. 31:202-222.

Tabrizian K, Yazdani A, Baheri B, Payandemehr B, Sanati M, Hashemzaei M, et al. Zinc chloride and lead acetate-induced passive avoidance memory retention deficits reversed by nico- 
tine and bucladesine in mice. Biol Trace Elem Res. 2016. 169: 106-113.

Takahama U. Scavenging of active oxygen by flavonoids. Tanpakushitsu Kakusan Koso. 1988. 33:2994-2999.

Takeda A, Suzuki M, Tempaku M, Ohashi K, Tamano H. Influx of extracellular $\mathrm{Zn}^{2+}$ into the hippocampal CA1 neurons is required for cognitive performance via long-term potentiation. Neuroscience. 2015. 304:209-216.

Takeda A, Tamano H, Tochigi M, Oku N. Zinc homeostasis in the hippocampus of zinc-deficient young adult rats. Neurochem Int. 2005. 46:221-225.

Takeda A. Zinc signaling in the hippocampus and its relation to pathogenesis of depression. J Trace Elem Med Biol. 2012. 26: 80-84.

Tamura T, Goldenberg RL, Ramey SL, Nelson KG, Chapman VR. Effect of zinc supplementation of pregnant women on the mental and psychomotor development of their children at $5 \mathrm{y}$ of age. Am J Clin Nutr. 2003. 77:1512-1516.

Tchantchou F, Lacor PN, Cao Z, Lao L, Hou Y, Cui C, et al. Stimulation of neurogenesis and synaptogenesis by bilobalide and quercetin via common final pathway in hippocampal neurons. J Alzheimers Dis. 2009. 18:787-798.

Tongjaroenbuangam W, Ruksee N, Chantiratikul P, Pakdeenarong N, Kongbuntad W, Govitrapong P. Neuroprotective effects of quercetin, rutin and okra (Abelmoschus esculentus Linn.) in dexamethasone-treated mice. Neurochem Int. 2011. 59:677-685.

Turner RS, Thomas RG, Craft S, van Dyck CH, Mintzer J, Reynolds BA, et al. A randomized, double-blind, placebo-controlled trial of resveratrol for Alzheimer disease. Neurology. 2015. 85:1383-1391.

Vinson JA. Flavonoids in foods as in vitro and in vivo antioxidants. Adv Exp Med Biol. 1998. 439:151-164.

Vitolo OV, Sant'Angelo A, Costanzo V, Battaglia F, Arancio O, Shelanski M. Amyloid $\beta$-peptide inhibition of the PKA/CREB pathway and long-term potentiation: reversibility by drugs that enhance cAMP signaling. Proc Natl Acad Sci USA. 2002. 99:13217-13221.

von Bülow V, Dubben S, Engelhardt G, Hebel S, Plümäkers B, Heine $\mathrm{H}$, et al. Zinc-dependent suppression of TNF- $\alpha$ production is mediated by protein kinase A-induced inhibition of Raf-1, IкB kinase $\beta$, and NF-кB. J Immunol. 2007. 179:41804186.
Wang HS, Xu YH, Chang S, Li L, Wang H, Hao JF. Protective effects of resveratrol nanosuspensions loaded in situ hydrogel on Alzheimer disease model mice after intranasal administration. Chinese J Pharmacol Toxicol. 2017. 41:468-469.

Wang Q, Xu J, Rottinghaus GE, Simonyi A, Lubahn D, Sun GY, et al. Resveratrol protects against global cerebral ischemic injury in gerbils. Brain Res. 2002. 958:439-447.

Wang Q, Yu S, Simonyi A, Rottinghaus G, Sun GY, Sun AY. Resveratrol protects against neurotoxicity induced by kainic acid. Neurochem Res. 2004. 29:2105-2112.

Warthon-Medina M, Moran VH, Stammers AL, Dillon S, Qualter $\mathrm{P}$, Nissensohn $\mathrm{M}$, et al. Zinc intake, status and indices of cognitive function in adults and children: a systematic review and meta-analysis. Eur J Clin Nutr. 2015. 69:649-661.

Yazir Y, Utkan T, Gacar N, Aricioglu F. Resveratrol exerts anti-inflammatory and neuroprotective effects to prevent memory deficits in rats exposed to chronic unpredictable mild stress. Physiol Behav. 2015. 138:297-304.

Youdim KA, Dobbie MS, Kuhnle G, Proteggente AR, Abbott NJ, Rice-Evans C. Interaction between flavonoids and the bloodbrain barrier: in vitro studies. J Neurochem. 2003. 85:180-192.

Youdim KA, Qaiser MZ, Begley DJ, Rice-Evans CA, Abbott NJ. Flavonoid permeability across an in situ model of the bloodbrain barrier. Free Radic Biol Med. 2004. 36:592-604.

Zaporowska H, Wasilewski W. Some selected peripheral blood and haemopoietic system indices in Wistar rats with chronic vanadium intoxication. Comp Biochem Physiol C: Comp Pharmacol. 1989. 93:175-180.

Zhao YN, Li WF, Li F, Zhang Z, Dai YD, Xu AL, et al. Resveratrol improves learning and memory in normally aged mice through microRNA-CREB pathway. Biochem Biophys Res Commun. 2013. 435:597-602.

Zhou DL, Feng CY, Lan YJ, Wang ZM, Huang S, Wang MZ, et al. Paired-control study on the effect of vanadium on neurobehavioral functions. Sichuan Da Xue Xue Bao Yi Xue Ban. 2007. 38:468-470.

Zhu JT, Choi RC, Chu GK, Cheung AW, Gao QT, Li J, et al. Flavonoids possess neuroprotective effects on cultured pheochromocytoma PC12 cells: a comparison of different flavonoids in activating estrogenic effect and in preventing $\beta$-amyloid-induced cell death. J Agric Food Chem. 2007. 55:2438-2445. 